\title{
As Vicissitudes da Duplicata no Brasil.
}

\author{
Waldírio Bulgarelli \\ Professor Livre Docente de Direito Comercial \\ da Faculdade de Direito da Universidade \\ de Sãa Paulo.
}

1. A série de problemas que a duplicata ${ }^{1}$ vem suscitando desde a promulgação da Lei 5.474 de 18 de julho de 1968, somados a todos os outros que provocou, desde a edição do Código Comercial de 1850, acentuam uma trajetória histórica das mais conturbadas, possivelmente sem paralelo com qualquer outro tipo de título de crédito.

$\mathrm{E}$ essa marcha acidentada se depara agora com novo episódio, decorrente da proposição pelo Assistente Jurídico da Comissão de Estudos Legislativos do Ministério da Justiça, Alfredo Nader, de Anteprojeto de Lei ${ }^{2}$, conferindo à duplicata sem aceite e protestada com comprovante de entrega da mercadoria, sem recusa formal e justificada do aceite, por parte do sacado, a qualificação de título líquido, certo e exigível para os efeitos do art. 586, do Código de Processo Civil e do art. $1^{\circ}$, do Decreto-Lei 7.661, de 21 de junho de 1945, o que vale dizer, ensejando quer a execução judicial, quer o pedido de decretação da falência do sacado ${ }^{3}$.

1. Referimo-nos à duplicata de fatura, aqui chamada simplesmente de duplicata, por economia e comodidade, sendo certo, porém, que se refere ao título regulado na Lei 5.764/68, com as alteraçöes do Decreto-lei 436, de 1969, abrangendo as duplicatas de serviços e as faturas ou contas dos profissionais liberais, sem conotação com a duplicata das Notas Promissórias, Letras de Câmbio e Cheques, conforme diciplinada nas leis cambiárias e nas Convenções de Genebra de 1930 e 1931, nem com a Duplicata Rural, regulada pelo Decreto-lei $167 / 67$.

2. Pareceres in Arquivos, n. ${ }^{\circ} 133$, março de 1975 , ps. $189 / 192$.

3. A providência tomada pelo Ministério da Justiça, no processo $22.609 / 74$, teve como base e fundamento, proposta da Diretoria e do Conselho do Instituto dos Advogados de São Paulo, memorial do advogado paulista Antonio da Silva Victor, e ainda manifestação da Associação dos Advogados de São Paulo. De ressaltar que quando da discussão do projeto de lei alterando a lei das duplicatas de que se originou esta Lei 5.474, atual, a Associação Comercial de São Paulo foi contrária aos dispositivos conferindo ação executiva à duplicata não aceita ou não devolvida, instruída com a prova da enitrega da mercadoria, havendo 
Teria assim referido Anteprojeto de Lei o condão de resolver de vez, dois dos problemas que afligem a vigência da duplicata atualmente, ou seja: a negativa em considerar a sem aceite, com o comprovante da entrega da mercadoria, como título executivo extrajudicial e a impossibilidade de servir de base a requerimento da falência do sacado; este último de entendimento pacífico, após decisão do STF (Rec. Ext. 75.543), e o primeiro ainda controvertido, embora os últimos julgados dos Tribunais paulistas tenham se inclinado para admitir a ação executiva ${ }^{4}$, e o próprio STF, pela $2 .^{\text {a }}$ Turma, tenha se decidido favoravelmente (RE 82514. SP. 17.2.1976 in $R T$ - Informa, 155/1976, p. 22).

2. A análise desses dois problemas que se têm revelado cruciais, um desde a promulgação da Lei $5.474 / 68$ e outro após a entrada em vigor do novo Código de Processo Civil, põe em causa toda uma problemática em torno desse discutido título de crédito que nem por ser original e nativo, tem podido demonstrar suas excelências em comparação com a Letra de Câmbio, a Nota Promissória e o Cheque, cujos problemas, hoje, decorrem muito mais dos choques produzidos com a aplicação dos preceitos das Convenções de Genebra, do que pela sua configuração jurídica ou pela sua utilização prática.

$\mathrm{E}$ é realmente surpreendente constatar que após tantos anos, ainda não se tenha chegado a um desate definitivo em torno dos seus problemas, não só no que se refere a sua natureza jurídica e o seu discutível enquadramento entre os títulos de crédito - o que de certa forma é até compreensível tendo em vista as dificuldades que a própria conceituação da natureza jurídica implica, da mesma forma como o da qualificação jurídica; o que entretanto, é absolutamente inaceitável é a não-solução dos problemas referentes a sua emissão, circulação, cobrança e conseqüentes efeitos, inclusive na esfera criminal, dada a importância de que se tem revestido, como título decorrente da venda mercantil ou serviços prestados, com ampla e abundante utilização, como instrumento mobilizador do crédito, pelos nossos comerciantes. Do que ressalta

\footnotetext{
agora quem apoie essa medida, desde que não considerada como título líquido e certo. Cf. José Ernesto de Lemos Chagas, Duplicata Sem Aceite - Título hábil para requerimento de Falência, in Rev. Dir. Merc.. nova fase, n. ${ }^{\circ}$ s $15 / 16,1974$, p. $243 / 45$.

4. Cf. os julgados: R.T. $478 / 135$, agosto, 1975; R.T. $479 / 112 / 3$, setembro 1975; R.T. $479 / 121 / 2$, setembro 1975; R.T. 481/115/6, novembro, 1975 ; Contra, R.T. 481/134/5, novembro, 1975; R.T. 472/141, fev. 1975; e ainda STF RE 78.057, D.J.U. 29-3-1974.
} 
o manifesto atrazo do nosso direito em relação a esse título, a ponto de já ter sido sugerida a adoção, entre nós, da "facture protestable" francesa ${ }^{5}$, título restrito à circulação bancária ${ }^{6}$, o que, se comprovada a sua inspiração na duplicata brasileira, acarretaria situação das mais curiosas, pois estaríamos a importar um título pretensamente mais aperfeiçoado para resolver os problemas daquele que originariamente criamos.

Desde a fatura consagrada no art. 219 , do nosso vetusto Código Comercial que, devendo ser assinada pelo vendedor e pelo comprador, (pormenor a que não tem sido dada a importância devida, em relação ao discutido problema do aceite presumido, pois que o comprador, em assinando, aceitava a fatura, restando-lhe ainda dez dias para fazer valer sua oposição, à falta da qual a fatura presumia-se líquida, não havendo assim, em rigor, aceite presumido, como enganadamente se pretende) comprovava a venda em grosso ou por atacado entre comerciantes, e à qual se aplicavam as disposições referentes aos títulos de crédito disciplinados no corpo do Código, por expressa disposição do art. $427^{7}$; passando pela sua fase fiscal, como instrumento também de recolhimento de tributos, até esta fase atual, que se pode denominar sem exagero, de bancária, pois desligou-se das conotações fiscais e foi agregada à sistemática financeira, sujeita à regulamentação do Conselho Monetário Nacional - ainda não se encontrou solução adequada para os diversos problemas que apresenta, tal a diversidade de posições, tanto da doutrina como da Jurisprudência ${ }^{8}$, a que se deve acrescer a péssima redação da Lei 5.474/68.

5. Sugestão feita por NELSON ABRÃo, em Duplicata sem Aceite, Executividade Falências, Ed. S.P., 1975, p. 66.

6. A propósito cf. o estudo de FÁBIo K. Comparato, in Révue Trimestrielle de Droit Commercial, janeiro, 1968.

7. De notar que o art. 427 do C. Comercial, mandava aplicar o disposto para letras de câmbio, também para as letras de terra, notas promissórias, e em geral para todos os créditos mercantis.

8. Entre as mais recentes: EunÁpio BoRges, Títulos de Crédito; Paulo Restiffe Netto, Novos Rumos da Duplicata, Ed. SP. 1974; J. C. Sampaio LAcerda, A Nova Lei sobre Duplicatas, Ed. R. 1969; Nelson ABRão, ob. cit.; Carlos Fulgêncio da Cunha Peixoto, Comentários à Lei das Duplicatas, 1971; Lauro Muniz Barretto, O Direito Novo da Duplicata, Ed. S.P., 1969; Hernani Estrela, in R.F. 234; Rubens Requião, Curso de Direito Comercial, Ed. S.P., 1972; além dos estudos dos processualistas, em artigos específicos, como o de Jose IgNácio Botelho de Mesquita, Da Liquidez Suficiente para requerer a falência, in Rev. Dir. Merc. n. ${ }^{\circ}$ 7, 1972. ps. 47 e sgs.; ANTonio CaRLos DE ARAuJo CinTra, in R.T., Informa, n..$^{\circ} 105$; ou nos comentários ao novo Código de Processo Civil, ou em obras sobre a Execução Civel, como a de 
E evidente que um título desta espécie, bastante singular em relação à teoria clássica dos títulos de crédito e ligado umbilicalmente não ao contrato de compra e venda em si, mas à sua execução (diferença marcante que propicia uma série de confusões na sua apreciação), aspirando a foros de originalidade, em nosso meio, utilizado intensamente pelos comerciantes, deveria de fato despertar controvérsias necessárias para o seu completo aperfeiçoamento, mas, não com tal dimensão a ponto de pôr em dúvida até mesmo a sua efetividade prática como título de crédito, ensejando uma insegurança inadimissível num instituto jurídico, cuja função implica justamente em segurança e certeza, bases afinal de toda a construção do direito cambiário e a razão essencial justificadora da sua existência ao lado do direito obrigacional comum.

Reflete também a insegurança comum em nosso meio na apreciação dos títulos causais, não só na própria configuração desses títulos ${ }^{9}$, mas também na confusão entre as relações extracartulares e a própria cártula, mercê da causa do título expressa através da literalidade.

Liga-se ainda à problemática do contrato de compra e venda que por tão antigo, nem por isso se apresenta perfeito, entre nós, apresentando uma série de problemas que vão desde a sua conceituação legal, até a sua regulação dúplice, pelo Código Civil e pelo Código Comercial, passando pelos prazos de reclamação das mercadorias, da entrega real e simbólica, da suportação dos riscos, das conseqüências do inadimplemento, da necessidade de notificação ou do depósito da mercadoria rejeitada, etc., sem falar na deturpação da cláusula "FOB" 10.

Insista-se também sobre o hábito, para não dizer o vício, dos sacados não devolverem ou não aceitarem as duplicatas emitidas, fato que está na base do principal problema, ou seja, o do aceite presumido, cujas orígens remontam à época da

\footnotetext{
CÂNDido Dinamarco, de 1973. A confirmar a divergência existente, ilustrativo é o último número da R.T. (483, janeiro, 1976) que publica três estudos, com diferentes conclusões, a saber: Dr. Renato Pedroso, p. 22; Mário Aguiar Moura, p. 235, e Carlos Alberto Chaves, p. 239 e sgs.

9. A propósito dessas conclusões, cf. o nosso estudo sobre Títulos de Crédito Rural, in R.T. 453/11/22, 1973.

10. Como ocorre com uma série de leis fiscais, principalmente, incentivadoras, que utilizam o termo $\mathrm{FOB}$, com várias significações arbitrariamente, fazendo crer que futuramente teremos os mesmos problemas existentes hoje nos Estados Unidos, onde a cláusula FOB autoriza qualquer interpretação.
} 
promulgação do Código Comercial ${ }^{11}$, o que faz com que surja o terceiro (a quem o emitente endossa a duplicata, em geral, descontando-a num Banco), antes do aceite. Nesse sentido, vêem-se os esforços do Legislador através da Lei 5.474/68 para regularizar certas situações, como por exemplo, a do art. $7 .^{\circ}$, $\S \S 10^{\circ}$ e $2 .^{\circ}$, que permite o aceite por manifestação do sacado, comunicando a retenção da duplicata para pagamento, até o seu vencimento.

Ora, a situação do terceiro perante a duplicata que após ter descontado, não é aceita pelo sacado seria realmente curiosa, não fosse triste; obrigado a protestá-la, por falta de aceite, para garantir o direito de regresso já que como veremos é enganosa a Lei ao considerar o emitente, sacador, "tireur", etc. como sujeito ao direito de regresso, quando de fato à ausência do aceite, é o devedor principal, causando danos ao sacado (pois, o protesto, entre nós, seja de que tipo for sempre abala o crédito de quem nele apareça, por força é evidente da indefectível tendência dos nossos Bancos de não quererem correr risco algum), e arcando também com o risco de ficar impossibilitado de executar o emitente se não protestar no prazo legal, e não tendo, neste caso, como apresentar o comprovante da entrega da mercadoria, que está em poder do emitente.

Neste caso, seria de boa prática que os Bancos ao descontarem as duplicatas sem aceite, exigissem também o comprovante da efetiva entrega da mercadoria, resguardando-se assim tanto da possibilidade de se encontrar perante uma duplicata simulada, como adquirindo o direito de protestar o título inteiramente de acordo com as prescrições da Lei, podendo acionar, executivamente, o sacado, o que a Lei poderia exigir como condição para a circulação da duplicata sem aceite.

A contrapartida da não devolução ou não aceitaç̃o se encontra num número não muito pequeno de duplicatas simu-

11. Esta situação que vem sendo apontada pelos comercialistas clássicos foi lembrada por FÁBIo Comparato, no seu estudo sobre as Factures Protestables, advertindo os franceses do que ocorria no Brasil: "Au Brésil, également, la disposition de l'article 219 du Code de commerce de 1850, obligeant le vendeur, dans les ventes en gros entre commerçants, à remettre à l'acheteur en duplicata, au moment de la livraison des marchandises, la facture de vente pour être signée de l'acheteur, qui en garderait un exemplaire, est vite tombée dans l'oubli, faute d'acceptation par les acheteurs. Il est vrai que le même article disposait qu'en cas d'absence de réclamation dans les dix jours suivant la livraison des marchandises, les factures seraient incontestables. Mais l'impossibilité de faire dresser un protêt de la facture annulait pratiquement l'effet de la règle. Il était donc plus avantageux d'émettre une traite pour le recouvrement du prix", p. 24. 
ladas, às quais a giria comercial, gostosamente, deu uma conotação térmica, apelidando-as de "duplicatas frias". Está o comerciante como qualquer um, sujeito a ser alvo do saque de uma duplicata, sem respaldo em qualquer negócio, muito menos a entrega da mercadoria, e em conseqüência, tendo o seu nome apontado no respectivo protesto (quando descontada), para efeito de garantia do direito de regresso, o que sem dúvida, como já anotamos, causa traumas e abalos psicológicos e de crédito. Neste caso, a Lei poderia, tendo em vista esta situação especialíssima da realidade brasileira, determinar que em caso de protesto por falta de aceite de duplicata, não acompanhada do comprovante da entrega da mercadoria, deveria ser omitido o nome do sacado, evitando assim os prejuízos a que ele está sujeito. Se a lei concentrou-se na efetiva entrega da mercadoria, nada mais correto do que exigir para sua circulação a juntada dos documentos comprobatórios dessa entrega e na sua falta, a omissão do nome do sacado, no instrumento do protesto por falta de aceite. Em termos de criação, evidentemente, que a imaginação não pode ficar limitada, a querer copiar os títulos existentes que, da duplicata, se distanciam enormemente.

3. É, portanto, perante tal realidade que se deve examinar o mecanismo de atuação da duplicata. Fica suspenso entre esses dois extremos: o da duplicata filha de legítima operação comercial com a entrega efetiva da mercadoria, e o da duplicata fria, ou das variantes de um negócio incompleto (assinatura falsificada, entrega de mercadoria incompleta, etc.) que quem vive o dia a dia comercial, conhece muito bem.

Pendularmente, portanto, oscilam as opiniões em favor de uma ou outra face, demonstrando que afinal o problema não é tão simples.

Destarte na sua configuração jurídica, permanece, por assim dizer, um título solto, não se integrando suficientemente nem ao contrato de compra e venda, nem à teoria geral dos títulos de crédito.

Com efeito, não se tendo vinculado inteiramente ao contrato de compra e venda, não se integrou também completamente aos títulos de crédito, ficando a oscilar entre os dois institutos, daí que a sua invocada originalidade não é senão esdruxularia.

Não se ligou ao contrato de compra e venda, porque a Lei, conquanto a ele se refira (art. $10^{\circ}$ ), não tira todas as conse- 
qüências, mas, limita a sua correlação apenas à execução do contrato, ou seja, à entrega da mercadoria. Aliás, ao referir-se à efetiva entrega, pôs em causa até mesmo a entrega simbólica, distanciando-se ainda mais desse contrato. De notar que sob tal aspecto, é bastante ampla a configuração do contrato de compra e venda, em nosso Código Comercial; admitindo práticas, como a venda de coisa incerta (art. 192) e a não fixação do preço (art. 193) ininquadráveis na sistemática da duplicata, ainda se apresenta como contrato meramente consensual ${ }^{12}$, diferentemente da conotação real que tomou na legislação francesa e na italiana. Somando-se a isso tudo, a possibilidade de emissão da duplicata, em vendas mercantis para pagamento contra a entrega de mercadoria ou do conhecimento de transporte, e em vendas para pagamento em prazo inferior a trinta dias, contados da data da entrega ou despacho das mercadorias (art. $3^{\circ}$ ), o que torna difícil, na prática, conciliar com a noção de efetiva entrega da mercadoria, tem-se realmente um cenário confuso. Ora, tem importância transcendental a exata conceituação do que seja efetiva entrega da mercadoria, para a caracterização da duplicata simulada ou não, com repercussões de monta na esfera criminal.

A propósito da questão criminal, recente decisão do Tribunal de Alçada Criminal de São Paulo (1. ${ }^{\mathrm{a}}$ Câmara, ap. 108.176, 25.6.1975), decidiu pela existência de duplicata simulada, não obstante conforme se infere do texto do Acórdão, haja havido tratativas entre as partes e mesmo um pedido de mercadorias, o que revela a existência de um contrato de compra e venda, nos termos do art. 191, do Código Comercial, perfeito e acabado. Também, no julgamento da Ap. 67.361, R.T. 462/382, abril, 1974, a 6. ${ }^{\text {a }}$ Câmara do mesmo Tribunal, condenou a emitente de duplicatas que ultrapassaram o valor das faturas. Embora, não tenha resultado prejuízo à sacada, entendeu o Acórdão que "o que a Lei penal visa acima de tudo é que haja seriedade nas operações mercantis de tal sorte que todo título de crédito lançado em circulação, tenha perfeita correspondência com um negócio efetivamente realizado, tenha, enfim, origem legítima

12. Walter T. Alvarez, Direito Comercial, $4 .^{\text {a }}$ Ed. SP., 1976, n. ${ }^{\circ} 492$, p. 469, com base em DARCY BESSONE e CUNHA GonçALves atribui ao contrato de compra e venda, entre nós, eficácia real. o que não autoriza o entendimento complementar do mesmo autor de que se trata de contrato real. A doutrina clássica, desde CAYRU, sempre o entendeu como contrato consensual. Sobre a base romana em que se assenta e seus atuais problemas, $C f$. o exaustivo trabalho de Ramon Badenes Gasset, El Contrato de Compraventa, 2 v., Ed. Madrid, 1968. 
e não constitua simulacro, mero papel destituído de valor, falso em seu nascedouro". Que há evidente exagero, em se tratando de punição criminal, verifica-se ainda mais da decisão do mesmo Tribunal, na apel. 86.859, que concluiu que "se a transação foi efetivamente realizada, embora suspensa, depois pela compradora, não há que falar em duplicata simulada, dada a ausência de dolo" (R.T. 471/353). O que mostra afinal, a comp.eta desorientação de nossos Tribunais em relação ao tema ${ }^{13}$.

Por outro lado, não se integrou aos títulos de crédito, pois não concebida como tal ${ }^{14}$, apenas se aplicam a ela alguns dispositivos da Lei cambiária.

A própria equiparação do reconhecimento da exatidão da duplicata, ao aceite dos títulos cambiários, foi bastante forçada, é necessário reconhecer.

De lembrar, a propósito, a candente repulsa de J. X. CARVALHO DE MENDONÇA, a essa aproximação da duplicata com a Letra de Câmbio. Com efeito, afirmava o Mestre: "a confusão que se vai estabelecendo entre as duplicatas (que continuaremos a chamar faturas fiscais, originalidade brasileira, solicitada pelos "gros bonnets", do comércio, para enforcarem os compradores do interior, estando, porém a servir de guilhotina para muitos deles), e as letras de câmbio é de tal ordem que passa como expressão corrente o aceite da duplicata para significar a assinatura aposta no reconhecimento da exatidão do seu saldo." (Tratado de Direito Comercial, v. VI, 3. ${ }^{a}$ parte, n. ${ }^{\circ}$ 1.461, ps. 176 e segs.).

$\mathrm{Na}$ linha de separação entre a duplicata e a letra de câmbio, deve-se anotar, inicialmente, que a Lei 5.474/68, mandou aplicar supletivamente, no que couber, os dispositivos sobre emissão, circulação e pagamento das letras de câmbio (art. 25), não inteiramente, como se procedeu em relação ao cheque, cujo decreto 2.591 , de 7 de agosto de 1912, manda aplicar ao cheque as disposições da Lei 2.044, de 31.12.1908, em tudo o que lhe for adequado, inclusive a ação executiva. A fórmula escolhida pelo Legislador, para a duplicata foi, portanto, mais restrita, a exemplo, aliás, do que ocorreu com os títulos de crédito rural, regulados pelo Decreto-lei 167/67.

13. A respeito do enquadramento do crime de emissão de duplicata simulada no art. 172 do Código Penal, conforme determina a Lei $5.474 / 68$, ou no art. 171 do mesmo Código, cf. a decisão do E.T.R.J., in R.T. 480/379.

14. Disso se apercebeu com a costumeira perspicácia, o jurista RuBENs Requião, Curso de Dir. Comercial, ob. cit. p. 522. 
A técnica de assimilação às letras de câmbio utilizada, não é, pois, das melhores, ensejando confusões, dada a configuração peculiar das duplicatas.

Podem ser apontados, sob tal aspecto, os seguintes desencontros entre o regime das letras de câmbio e o das duplicatas:

1. em relação à prova do pagamento; admite a Lei 5.474/68 (art. $9 .^{\circ}, \S 1 .^{\circ}$ ) o recibo passado pelo legítimo portador ou por seu representante com poderes especiais, em documento separado com referência expressa à duplicata ; também permite-se como prova do pagamento total ou parcial da duplicata, a liquidação do cheque, a favor do estabelecimento endossatário, no qual conste, no verso, que seu valor se destina à amortização ou liquidação da duplicata nele caracterizada (art. $9 .^{\circ}, \S 2 .^{\circ}$ );

2. efeitos do aval póstumo - o $\S$ único, do art. 12, não distingue entre o aval dado antes ou depois do vencimento da duplicata;

3. o aceite através de comunicação, com a conseqüente retenção da duplicata, pelo sacado (art. $\left.7 .^{\circ}, \S 1 .^{\circ}\right)$;

4. a falta de precisão no valor da duplicata - o que se infere do disposto no art. $3 .^{\circ}$ e seus parágrafos, admitindo-se "rebate" (o que deve significar, por certo, desconto) com valor bruto e valor líquido, além dos abatimentos de preços, constantes da fatura. Também os pagamentos em prestações, decorrentes da possibilidade de, nas vendas para pagamentos em parcelas, ser emitida duplicata única, discriminando todas as prestações e seus vencimentos;

5. execução sem o título - no caso do art. $15, \S 15$, que confere ação executiva, desde que acompanhada a duplicata, do protesto tirado por indicações e com comprovante da remessa ou da entrega da mercadoria;

6. a equiparação ao aceite cambial da declaração de reconhecimento da exatidão da duplicata e da obrigação de pagá-la (art. $2 .^{\circ}, 1 .^{\circ}$, vIII).

No tocante, especificamente, à circulação, ponto básico em que se assentam os títulos de crédito, a circulação sem o aceite, 
obrigaria para ser completa, que a duplicata fosse acompanhada do documento comprobatório da entrega ou remessa da mercadoria ${ }^{15}$, para possibilitar a terceiro (em regra, o Banco que a descontou) a ação executiva contra o sacado. Como em geral prefere este (o terceiro) voltar-se contra o emitente-endossante, a circulação fica obviamente restrita.

De se dar destaque também às impropriedades terminológicas da Lei, que não contribuem para amenizar as dificuldades com que já luta o intérprete. Sem nos determos no verdadeiro enígma em que se constituiu a redação do art. $5^{\circ}$ e seus dois parágrafos, segredo que o Legislador conseguiu guardar admiravelmente, sob a capa de uma redação ininteligível, é de se acentuar as variadas aplicações dos termos emitente, sacador, endossante, vendedor, sacado, devedor, comprador, esquecendo-se, por vezes, de que o emitente é também o primeiro endossante (diversamente da letra de câmbio, salvo é evidente quando emitida em favor do próprio sacador), e o emprego dos verbos expedir, emitir, e extrair, indiscriminadamente.

4. Nunca tendo chegado, portanto, a adquirir integralmente a natureza de título de crédito, tangenciando apenas o direito cambiário, também não se aproximou o suficiente do contrato de compra e venda, ficando assim como um título incomum, quase um "imbroglio", em termos de direito cambiário e de direito obrigacional, obrigando o intérprete a verdadeiros exercícios de imaginação para poder concluir algo a respeito.

De não estranhar, pois, tenha sido considerado como título "sui generis" 16.

Ao que se deve acrescer, hoje, a conotação bancária. Com efeito, a determinação contida no art. 27 da Lei 5.474/68, ao Conselho Monetário Nacional para que baixasse normas para a padronização formal dos títulos e documentos nela referidos (o que veio a ser efetivado pela Resolução $n^{\circ}{ }^{\circ} 102$, de 26.11.1968) ${ }^{17}$, autoriza o entendimento de que neste atual estágio, a duplicata convolou-se em título bancário. Outras disposições da Lei, confirmam esse entendimento, como o disposto no art. $6 .^{\circ}$ sobre a remessa feita por intermédio de instituição financeira, etc.

15. Conforme advertiu Eunápio BoRges, em relação aos problemas advindos do emprego das duas expressões, significando posições totalmente contrárias.

16. Cf. FÁbio Pena, ob. cit. . 
Aliás, a tendência de ligar a duplicata às instituições financeiras nota-se, claramente, na França, onde as "factures protestables" são títulos destinados exclusivamente a serem negociados com os Bancos ${ }^{18}$. Essa verdadeira restrição à circulação, que não produziu resultados na França, onde é considerado um título sem sucesso, afasta-a mais das letras de câmbio e das notas promissórias.

Referida tendência, na França, vem se acentuando, para eliminar os gastos que a circulação acarreta aos Bancos. Nesse sentido, a criação da L.C.R. ("Lettres de change relevé) é bastante ilustrativa: inspirou-se na idéia de manter o uso da "traite", completando-a contudo, com documentos circuláveis entre os Bancos, dispensando-se assim a passagem da letra de mão a mão, para se obter o resgate, mediante a prova do pagamento sem a entrega da letra ao devedor sacado. A empresa credora emite letras de câmbio contra os devedores; essas letras são enviadas ao Banco para desconto ou cobrança; mas, não circulam, sendo conservadas pelo Banco para o caso de não pagamento ou contestação; o que circula entre os Bancos são as características das letras transpostas sobre uma banda magnética ${ }^{19}$.

Embora como título causal, a duplicata circule pesadamente, não tão alígera como os títulos abstratos, a verdade é que da forma como foi concebida, sua circulação plena é bastante problemática. Na prática, pode-se dizer que se resume a ser negociada com os Bancos, e afora ele, quando muito, dada em compensação ou pagamento de aquisições, pelas empresas.

Em sendo assim, afasta-se mais da Letra de Câmbio, tanto mais que é punida criminalmente a duplicata sem causa, enquanto a Letra de Câmbio não o é. Isto por si só já faria ser superior à sistemática da Letra de Câmbio, até por que não é mais obrigatória a emissão da duplicata, embora em contra-partida, não se admita a emissão de qualquer outro título afora a duplicata, para documentar saque sobre compra e venda. Claro que em nossa prática, seria quase impossível

17. O que faz supor tenha sido revogado o art. 24, da mesma Lei, 5.474, que permitiu constasse da duplicata outras indicações, além daquelas previstas no art. $2 .^{\circ}$, § $10^{\circ}$, desde que não alterassem sua feição característica.

18. Tal como dispõe o art. $4 .^{\circ}$, da Ord. n. $.^{\circ} 67-838$, de 28.9.1967. Cf. FábIo K. Comparato, ob. cit. p. 26. 1973.

19. Rene Rodière e Jean-Louis River-Lange, Droit Bancaire, Ed. Dalloz, 
a obtenção de crédito, com base em Letras de Câmbio sem aceite, por força não só da tradição, mas, também porque a Letra de Câmbio prescinde da indicação da causa, enquanto a duplicata deve provir necessariamente de um venda.

Vê-se, portanto, mais uma vez as duas faces do dilema: proteção aos que emitem e negociam a duplicata, ou dos que são alvo das forjadas ou das contestáveis.

5. Tem a seu favor o comprador, a possibilidade de recusar o aceite, nos casos fixados no art. $8^{\circ}$; avaria ou não recebimento das mercadorias, quando não expedidas ou não entregues por sua conta e risco; vícios, defeitos e diferenças na qualidade ou na quantidade das mercadorias, devidamente comprovados; divergência nos prazos ou nos preços ajustados. Essas razões deverão, se for o caso, constar do instrumento de protesto (art. 29, III, da Lei 2.044/1908), cabendo ação ordinária ao credor para elidí-las.

Parecendo ser suficiente esse mecanismo de defesa, no entanto esbarra na obrigatoriedade do protesto para assegurar o direito de regresso, por parte do portador da duplicata. Descontada a duplicata, perante a recusa do aceite, o Banco terá que protestá-la para garantir-se. Ora, no instrumento constará o nome do sacado e apesar de nele aparecer também as razões invocadas, sofrerá as conseqüências da estranha repulsa dos banqueiros pelo protesto, ainda que por falta de aceite. Daí o recurso utilizado da suspensão provisória ou definitiva do protesto, por parte dos sacados, a pretenderem sua exclusão do protesto, aliás, dentro do vício também brasileiro, de se considerar que o protesto é feito contra alguém, quando na verdade se trata apenas de meio de prova do não cumprimento da obrigação constante do título.

Admitida a ação executiva ou pedido de falência contra - sacado que não aceita a duplicata, acompanhada esta do comprovante da entrega da mercadoria e respectivo protesto, fica o sacado, obviamente, em situação de inferioridade no processo; terá de provar que a entrega da mercadoria lhe não foi feita, que a mercadoria não correspondia ao pedido ou mesmo que houve erro na fatura. Poder-se-á objetar que deveria ter providenciado a comunicação dos motivos porque não aceitou a duplicata ou mesmo oferecido tais razões por ocasião do protesto, o que é bastante justo; sob tal aspecto a inércia do comprador não pode chegar a tanto. Vítima, por exemplo, de desvio da mercadoria, quer pela transportadora, quer pela falsidade da assinatura, ou pela assinatura de quem 
não estava autorizado - terá ensejo senão antes ao menos até o protesto de apurar tais fatos, assinalando-os como motivo de recusa; também, por vícios, defeitos, etc. Parece, pois, bem defendido o comprador, desde que se admita que a invocação dos motivos previstos no art. $80^{\circ}$ destrua a liquidez da duplicata.

A propósito, não se justifica a prisão do sacado, pela não devolução da duplicata, uma vez que é obrigatória a emissão de triplicata, pela perda ou extravio da duplicata. De tal arte que não convencem os argumentos expendidos pelos ilustres magistrados da 1. a Turma do STF ("Habeas Corpus" $52.613 / 1974$, in R.T. 481/418, novembro, 1975), em julgamento, cuja ementa é a seguinte: "A prisão do sonegador de duplicata enviada para aceite tem amparo legal. 0 art. 885, do atual Código de Processo Civil, reproduz norma que longe está de ser novidade, porque já prevista, além do Código de Processo Civil revogado, na lei cambial (art. 31, parágrafo único, do Dec. 2.044/1908)." Não tendo a Lei das duplicatas repetido o dispositivo da Lei cambiária (quando poderia fazê-lo) somente mandando aplicar os dispositivos sobre emissão, circulação e pagamento da Lei cambiária, no que couber, também afastou-se da sistemática da Lei cambiária obrigando à extração da triplicata. Não se compreende, pois, perante a extração da triplicata, a prisão do sacado pela não devolução de duplicata. Por outro lado, é de não esquecer que o art. 885 do novo C. P. Civil, em sendo de natureza processual, pressupõe, contudo, dispositivo de lei material, entendimento que é confirmado pelo disposto no próprio art. 882 do mesmo Código de Processo.

Essa aproximação à Lei cambiária é descabida tanto formal (uma vez que a Lei das duplicatas não mandou que se aplicassem tais dispositivos da Lei cambiária) como substancialmente de vez que a sistemática da duplicata, impondo a extração da triplicata, afasta qualquer processo de violência contra o sacado que retém a duplicata, sem se falar na possibilidade de protesto e execução de duplicata, por indicações ${ }^{20}$.

6. Por seu turno, o vendedor que emite a duplicata, com base em mercadoria efetivamente entregue ou despachada por meios idôneos, deverá ter o direito de acionar, com efetividade o sacado. Constituindo a não devolução da duplicata ou a sua não aceitação o verdadeiro drama do comércio brasileiro, sobre

20. E de se ressaltar, a propósito, a existência de fórmulas mais brandas no processo, como o seqüestro, ou outra medida cautelar inespecífica. Cf. a respeito, quanto à Nota Promissória, Acórdão do T.J.P.R., in R.T. 478/163. 
essa hipótese teria de se concentrar o Legislador. Daí o surgimento desse impropriamente denominado aceite presumido, visando o mecanismo criado pela Lei, a suprir, por outro meio de prova, a omissão (intencional ou não) do comprador. Não aceitando (e não dizendo porque) ou não devolvendo a duplicata, deu-se ao sacador que possa provar a entrega ou a remessa da mercadoria, a ação executiva e até mesmo a possibilidade de requerer a falência do comprador omisso.

$\mathrm{E}$, embora com defeitos de redação, os mecanismos da Lei $5.474 / 68$, sob tal aspecto, foram um achado. Deixando de ser obrigatória a emissão da duplicata (despida agora das suas conotações fiscais) condicionou, quando escolhida a duplicata (é o único título que pode ser utilizado), sua emissão e circulação ao procedimento que instituiu, indo até as minudências de natureza processual, a fim de evitar as eternas interpretações arabescas e parceladas tão habituais no âmbito processual. Protegeu, portanto o sacador, dando-lhe amplas possibilidades de executar o sacado.

Trouxe, em conseqüência, um verdadeiro remanso na acidentada trajetória da duplicata entre nós, conferindo a ação executiva com rito sumaríssimo, facilitadas as formalidades processuais e encolhidos os prazos.

Infelizmente durou pouco tal calmaria; as discussões sobre a possibilidade da falência com base em duplicata não aceita e posteriormente com o advento do novo Código de Processo Civil, a inaceitação da permanência dos dispositivos processuais na Lei de duplicatas contidos, e a própria recusa em conferir à duplicata, não aceita, o caráter de título executivo extra-judicial, subverteram o antigo correto procedimento.

Esqueceram-se, por certo, ou desconheceram, os que, na linha processualista, voltaram-se contra os dispositivos da Lei da duplicata, a problemática desse título, ficando enrodilhados em argumentos de ordem puramente formal, sem que afinal fossem os mais corretos.

Confundiram assim liquidez com quantia certa, e certeza, com a expressa assinatura do sacado; desprezaram os variados graus de certeza que o legislador considera suficiente para ensejar a pretensão processual e nesse diapasão acabaram por considerar impropriamente a ação executiva e a falimentar, confundindo sentença condenatória e declaratória.

Pôs ordem nessas discussões improfícuas e mal fundamentadas, em conciso e precioso trabalho (que, inexplicavelmente não vem referido nas bibliografias citadas, pelos Autores), 
datado de 1972, o jurista JosÉ IGNÁCIO BotelHo DE MESQUITA ${ }^{21}$. Assim é que a propósito das discussões sobre o aceite conferindo certeza à obrigação, conclui que: "Em resumo, parece ser totalmente infrutífera a discussão sobre se o que torna a obrigação líquida é apenas aceite expresso ou se a tanto bastaria o aceite tácito, pois, como dissemos, nenhum dos dois confere certeza à obrigação e nos dois casos a certeza quanto aos fatos é igualmente contestável e igualmente sujeita à prova em contrário" (p. 48).

Concluindo em relação à ação executiva e à ação falimentar que "Se fosse verdadeiro que a ação executiva contém apenas pretensão de cobrança e que a ação falimentar contém apenas pretensão declaratória - o que evidentemente se contesta não seria certo dizer que a certeza suficiente para a admissibilidade da primeira não seria suficiente para a segunda, pois, o verdadeiro seria exatamente o contrário já que a eficácia de uma sentença meramente declaratória é sempre inferior a de uma sentença condenatória (CPC art. 290). Seria uma incongruência do legislador ampliar as exigências para quem pede o menos e diminuí-la para quem pede o mais. Na realidade, contudo, tanto a ação executiva como a ação falimentar, ao lado de suas diferenças óbvias, guardam entre si estreita correlação no que concerne à pretensão, que em ambas se contém, de fazer atuar o poder executório, bastando-lhes a existência de título executivo. Em tais condições, o requisito imposto pelo Estado para a atuação do seu poder executório, não pode ser diverso num e noutro caso. Neste particular e só neste, em vez de diferença entre ambos os procedimentos o que se tem é igualdade."

7. Entende-se que do ponto de vista da realidade do comércio jurídico, tenha parecido um remédio forte demais a permissibilidade da ação falimentar para a duplicata não aceita. Sem dar realce ao fato de que o requerido no processo falimentar não está sem defesa, pelo contrário, a Lei lhe oferece amplamente esse direito, acentuou-se o argumento da eqüidade, pelas repercussões sobre o crédito do suposto falido e as próprias dificuldades oferecidas para a sua defesa. Assim é que entendeu-se que o suprimento do aceite para efeito da ação executiva não constitui risco, pois a instância pode ser garantida pela penhora e admite ampla discussão sobre a legitimidade

21. Da Liquidez suficiente para requerer falência, in Rev. Dir. Merc. nova fase, n. ${ }^{\circ} 7,1972$. 
da cobrança, além do exame circunstanciado das provas, sendo a maior ameaça a penhora. No caso de falência, contudo, o seu pedido provocaria comoção social, com grave abalo no crédito, anotando-se o poder intimidatório desse pedido que poderia levar ao pagamento indevido, pois a defesa só é permitida após o depósito da quantia exigida, o que se tornaria difícil ou quase impossível em caso de grandes quantias ${ }^{22}$.

Muito embora, o panorama não seja assim tão sombrio, pois que o requerido tem amplas possibilidades de defesa, no processo falimentar, até mesmo sem o depósito da quantia exigida desde que alegue motivos de alta importância ${ }^{23}$, há que se convir, contudo, que, por esse aspecto há razões relevantes que, refugindo às estritamente formais, encontram apoio na realidade fáctica.

Se o simples protesto de duplicata por falta de aceite já enseja abalos no crédito do sacado, que dizer-se então de um requerimento de falência?

Tratando-se de argumentos justos, não se deve esquecer contudo a outra face do problema, ou seja, a situação do vendedor que espera receber o correspondente ao preço da mercadoria entregue ou despachada, ou do terceiro que de boa-fé descontou o título.

Foi nessa linha do dilema, que o Anteprojeto do Ministério da Justiça tentou solucionar a questão.

$O$ texto que transcrevemos a seguir, manteve a possibilidade do protesto da duplicata não aceita ou não devolvida, desde que acompanhado de documento hábil comprobatório da entrega da mercadoria e conferindo-lhe o "status" de título executivo extrajudicial, condicionado porém a que o sacado não tenha, comprovadamente, recusado o aceite, no prazo $\theta$ condições e pelos motivos previstos nos artigos 7..$^{\circ}$ (apresentação no prazo e comunicação por escrito do sacado do aceite e da retenção até o vencimento) e $8 .^{\circ}$ (avaria etc.).

Estende também a possibilidade do requerimento da falência à duplicata assim instruída, conforme se verifica do art. $2 .^{\circ}$, no que se inseriu na linha preconizada por José I. B. Mesquita, de vez que se confere uma, não há como negar a outra.

22. Cf. Jost ERnesto de Lemos Chagas, ob. cit. p. 244.

23. Nesse sentido julgou o Tribunal de Justiça de Santa Catarina, in R.T. $468 / 190$, out. 1974. Em relação às defesas do requerido, cf. R.T. 493/61, 421/177, $119 / 775,130 / 564,152 / 459,242 / 291,261 / 352,265 / 542,381 / 158,384 / 173,450 / 88$, 451/116. 
Dando, porém, efeito obstativo à reclamação a tempo do sacado, garante-o contra execuções temerárias, o que nos parece ser do maior acerto.

Faltou, a nosso ver, resolver apenas mais duas questões: a) a referente à circulação do título com os comprovantes da entrega, quando ainda não aceita; b) a lavratura do protesto, sem a menção do nome do sacado, quando por falta de aceite; sem a prova da entrega da mercadoria, e nos casos em que - sacado tenha recusado o aceite, fundado nos permissivos da Lei ${ }^{24}$.

OBSERVAÇAO: 0 projeto referido neste artigo, foi convertido na Lei n. ${ }^{\circ} 6.458$, de $10^{\circ} .11 .1977$, com o seguinte teor:

LEI N. 6.458, DE $10^{\circ}$ DE NOVEMBRO DE 1977

Adapta ao Código de Processo Civil a Lei n.o 5.474, de 18 de julho de 1968, e dá outras providências.

O Presidente da República,

Faço saber que o Congresso Nacional decreta e eu sanciono a seguinte Lei:

Art. $10^{\circ}-0 \S 2 .^{\circ}$ do art. $70^{\circ}$, o Capítulo $\mathrm{V}$ (arts. 15 a 18 ) e $0 \S 4 .^{\circ}$ do art. 22 da Lei $n .^{\circ} 5.474$, de 18 de julho de 1968 , passam a vigorar com a seguinte redação:

"Art. $7 .^{\circ}$

$\S 2 .^{\circ}$ - A comunicação de que trata o parágrafo anterior substituirá, quando necessário, no ato do protesto ou na execução judicial, a duplicata a que se refere.

\section{CAPfTULO V}

\section{Do Processo para Cobrança da Duplicata}

Art. 15 - A cobrança judicial de duplicata ou triplicata será efetuada de conformidade com o processo aplicável aos títulos executivos extrajudiciais, de que cogita o Livro II do Código de Processo Civil, quando se tratar:

I - de duplicata ou triplicata aceita, protestada ou não;

II - de duplicata ou triplicata não aceita, contanto que, cumulativamente:

a) haja sido protestada;

b) esteja acompanhada de documento hábil comprobatório da entrega e recebimento da mercadoria; e

c) o sacado não tenha, comprovadamente, recusado o aceite, no prazo, nas condições e pelos motivos previstos nos arts. $7 .^{\circ}$ e $80^{\circ}$ desta Lei.

$\S 10^{\circ}$ - Contra o sacador, os endossantes e respectivos avalistas caberá o processo de execução referido neste artigo, quaisquer que sejam a forma as condiçôes do protesto.

§ 2.0 - Processar-se-á também da mesma maneira a execução de dưplicata ou triplicata não aceita e não devolvida, desde que haja sido protestada mediante indicações do credor ou do apresentante do título, nos termos do art. 14, preenchidas as condições do inciso II deste artigo. 
Art. 16 - Aplica-se o procedimento ordinário previsto no Código de Processo Civil à ação do credor contra o devedor, por duplicata ou triplicata que não preencha os requisitos do art. 15 , incisos I e II, e $\S 1^{\circ}$ e $2 .^{\circ}$, bem como à ação para ilidir as razões invocadas pelo devedor para o não aceite do título, nos casos previstos no art. $8 .^{\circ}$.

Art. 17 - $O$ foro competente para a cobrança judicial da duplicata ou da triplicata é o da praça de pagamento constante do título, ou outra de domićlíio do comprador e, no caso de ação repressiva, a dos sacadores, dos endossantes e respectivos avalistas.

Art. 18 - A pretensão à execução da duplicata prescreve:

I - contra o sacado e respectivos avalistas, em 3 (três) anos, contados da data do vencimento do título;

II - contra endossante e seus avalistas, em 1 (um) ano, contado da data do protesto;

III - de qualquer dos coobrigados contra os demais, em 1 (um) ano, contado da data em que haja sido efetuado o pagamento do título.

$\S 10^{\circ}$ - A cobrança judicial poderá ser proposta contra um ou contra todos os coobrigados, sem observância da ordem em que figurem no título.

$\S 2 .^{\circ}-O$ coobrigados de duplicata respondem solidariamente pelo aceite e pelo pagamento.

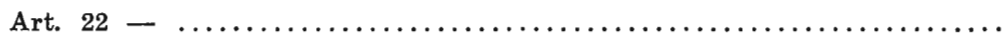

$\$ 4 .^{\circ}-0$ instrumento do protesto, elaborado com as cautelas do art. 14, discriminando a fatura ou contra original ou a certidão do Cartório de Títulos e Documentos, autorizará o ajuizamento do competente processo de execução na forma prescrita nesta Lei."

Art. 2. ${ }^{\circ}$ - Para os efeitos do art. 586 do Código de Processo Civil, considera-se título líquido, certo e exigível a duplicata ou a triplicata que, nos termos da Lei $n .^{\circ} 5.474$, de 18 de julho de 1968 , com as alterações introduzidas por esta Lei, legitimar o processo de execução.

Art. 3. $0^{\circ}$ - Fica acrescentado ao art. $10^{\circ}$ do Decreto-lei $n .^{\circ} 7.661$, de 21 de junho de 1945, Lei de Falências, o seguinte parágrafo:

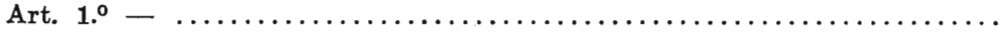

$\S 3 .^{\circ}$ - Para os efeitos desta Lei, considera-se obrigação líquida, legitimando - pedido de falência, a constante dos títulos executivos extrajudiciais mencionados no art. 15 da Lei $n .^{\circ} 5.474$, de 18 de julho de 1968."

Art. $4 .^{\circ}$ - Esta Lei entrará em vigor na data de sua publicação.

Art. 5. - Revogam-se as disposições em contrário.

Brasília, em 01 de novembro de $1977 ; 156 .^{\circ}$ da Independência e $89 .^{\circ}$ da República.

ERNESTO GEISEL

Armando Falcão

24. No sentido apontado, já se verificaram decisões dos Tribunais, como a seguinte: "Se o sacado comunica ao Banco endossatário que não aceita a duplicata por não existir contrato de compra e venda por não ter recebido a mercadoria, ou ainda, por não ter ocorrido qualquer dos motivos discriminados no Art. 13, da Lei 187 , não pode o estabelecimento bancário protestá-la contra - primeiro sacado. Poderá sim e só, protestá-la contra o endossante, isto é, contra o emissor da duplicata endossada ao banco, e isto para assegurar o direito de regresso contra ele, cumprindo destacar que, em se tratando de duplicata simulada, esse direito prevalece mesmo não havendo aquele protesto contra o endossante sacador" in R.T. 205/302 